\title{
Glycogen-Rich Carcinoma
}

National Cancer Institute

\section{Source}

National Cancer Institute. Glycogen-Rich Carcinoma. NCI Thesaurus. Code C4153.

A carcinoma characterized by the presence of malignant epithelial cells with abundant clear cytoplasm which contains glycogen. A representative example is the glycogen-rich, clear cell breast carcinoma. 